\title{
Journal of Clinical and Laboratory Research
}

Fé Fernández Hernández *

\section{Behavior from the Mortality in Cuba 1990 - 2018}

Efraín Sánchez González MD ${ }^{1}$, Fé Fernández Hernández MD ${ }^{1 *}$

${ }^{1}$ Auxiliary Professor. Faculty of Medical Science, at University of Medical Science of Havana.

*Corresponding Author: Fé Fernández Hernández, Auxiliary Professor. Faculty of Medical Science, at University of Medical Science of Havana.

Received date: May 07, 2021; Accepted date: May 17, 2021; Published date: May 20, 2021

Citation: Efraín S González, Fé F Hernández. (2021) Behavior from the Mortality in Cuba 1990 - 2018. Journal of Clinical and Laboratory Research. 2(5) DOI: 10.31579/2768-0487/025

Copyright: (@2021 Fé Fernández Hernández. This is an open-access article distributed under the terms of the Creative Commons Attribution License, which permits unrestricted use, distribution, and reproduction in any medium, provided the original author and source are credited.

\begin{abstract}
Introduction. Mortality behavior is close related to the human develop. Countries with higher life expectancy have more opportunity to develop their producer forces and become this develop in economic grow and social development. These reasons appoint to a closer researching about the behavior from main death causes in Cuba.
\end{abstract}

Objective. To describe the behavior from the mortality in Cuba from 1990 to 2018.

Methods. Was made a descriptive research about the behavior from the mortality in Cuba from 1990 to 2018 . As teoricals methods were used the inductive - deductive, the comparative and the historic-logic. As empiric methods were used the bibliographic research and the Ordinary Less Square. All graphs and equation were obtained using MS Excel 2007.

Results. The middle incidence rate is close to 91 deaths annually by death cause. From the 10 main death causes in Cuba, Hearth illness, Cancer, Brain vascular illness and Flu and pneumonia are the most significant in the researched period. All these four death causes show a higher incidence rate than the middle from the ten, being the mortality by cancer the most relevant.

Conclusions. From the ten main death causes in Cuba from 1990 to 2018, Hearth illness, Cancer, Brain vascular illness and Flu and pneumonia are the more significant because all them are growing during all time researched.

Key words: mortality; cause; behavior

\section{Introduction}

Mortality is a main variable explaining the demographic behavior [1]. Developed countries are characterized by low born rate and long life expectancy [2]. Also, the main death causes in these countries are given by no communicative illnesses; agree to the self-epidemiologic transition step [3].

Some developing countries as Cuba show a small population growing rate. This situation is explained by lower born rate and a negative migration relation [4]. However, countries in the same epidemiologic transition step that Cuba show higher life expectancy where the role from the no communicative illnesses is more significant every time [5].

Mortality behavior is close related to the human develop. Countries with higher life expectancy have more opportunity to develop their producer forces and become this develop in economic grow and social development [6].

These reasons appoint to a closer researching about the behavior from main death causes in Cuba. That's why the main objective from this research is to describe the behavior from the mortality in Cuba from 1990 to 2018 .

\section{Methods}

Was made a descriptive research about the behavior from the mortality in Cuba from 1990 to 2018. As teoricals methods were used the inductive deductive, the comparative and the historic - logic. As empiric methods were used the bibliographic research and the Ordinary Less Square. All graphs and equation were obtained using MS Excel 2007.

\section{Results}

The ten main death causes in Cuba in the period from 1990 to 2018 had been the following:
1) Hearth illness
2) Cancer
3) Brain vascular illness
4) Flu and pneumonia
5) Accidents
6) Chronic illness from the inferior breathing ways
7) Illness from the arteries and blood vessels
8) Diabetes mellitus
9) Cirrhosis and other chronic illness from the liver
10) Self-damage [7].

The incidence rate growing from the whole group in this period had been superior to 900 deaths annually, as show the following graph. 


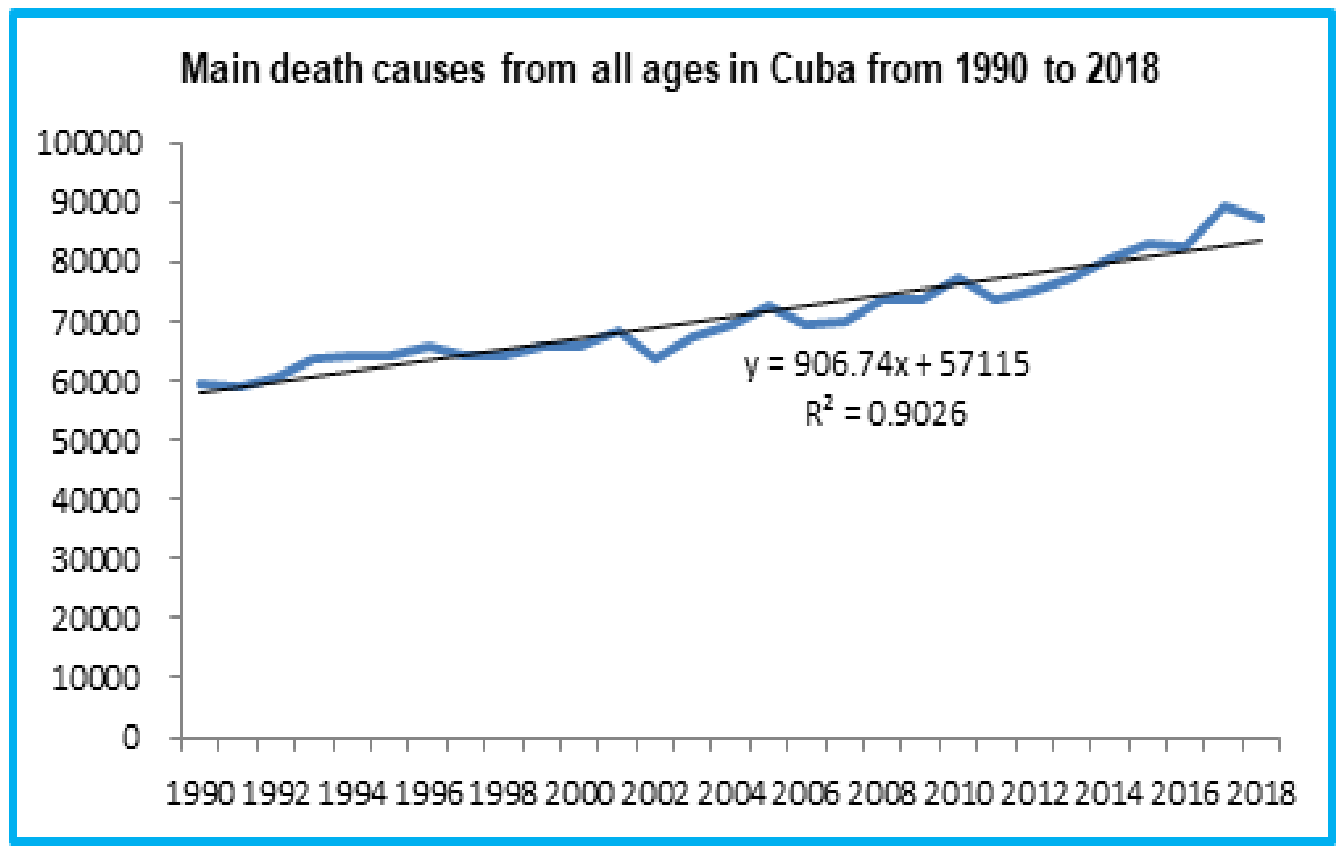

Graph made using information from the Cuban Statistic Yearbook

From these death cause the first four had been the most representative in the dynamic from the Cuban mortality, as show the following graph.

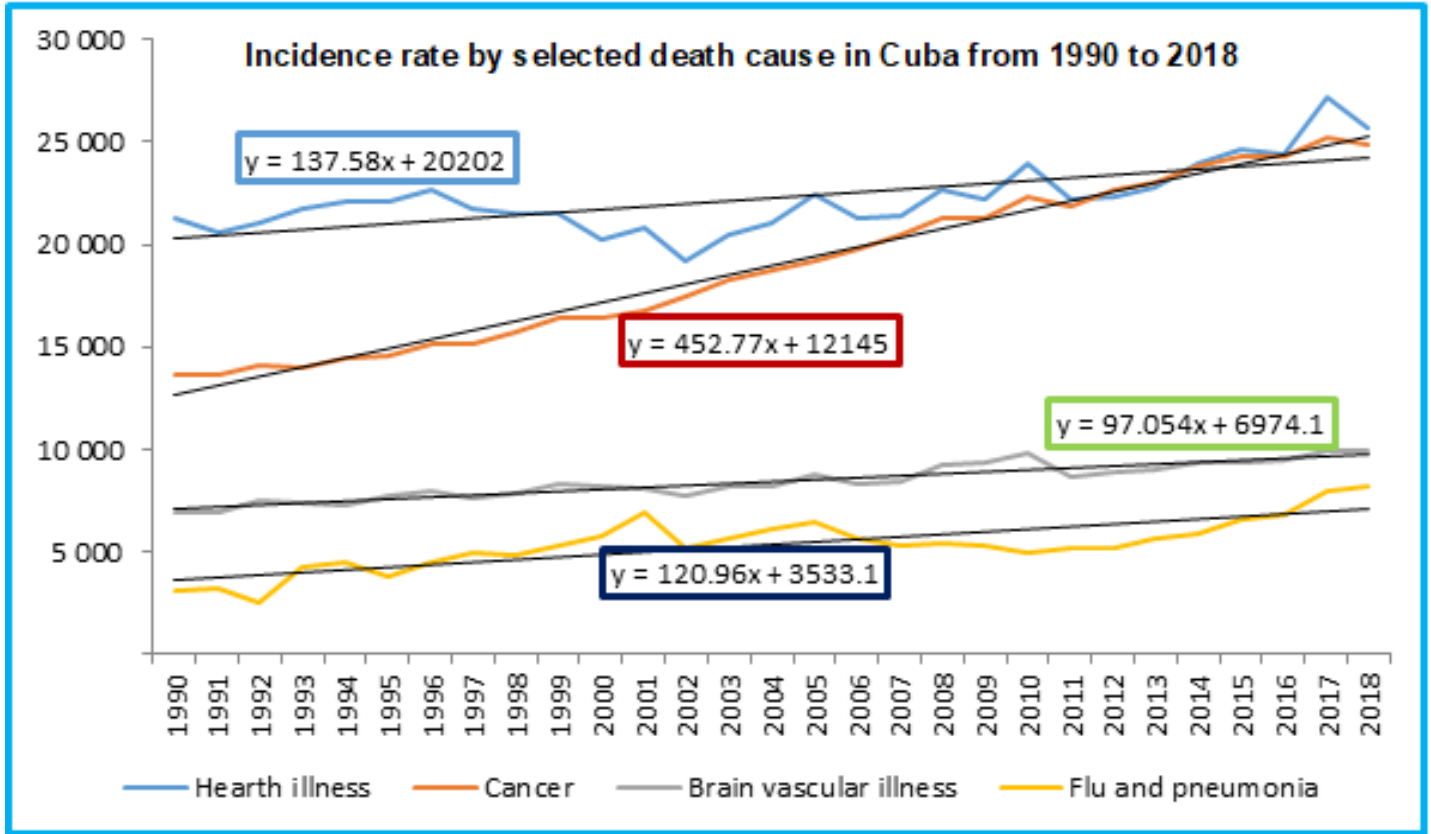

Graph made using information from the Cuban Statistic Yearbook

This graph shows significant information from the Cuban mortality behavior. In first place, in absolute terms the ranking from these death causes is given by hearth illness, cancer, brain vascular illness and flu and pneumonia in that order. However, considering the annual incidence rate growing the raking is given by cancer, hearth illness, flu and pneumonia and brain vascular illness in that sequence.

Particularly the growing in incidence rate from the mortality by cancer is superior to the other three as whole and is the half from the growing in incidence rate from the 10 main death causes in Cuba. This information suggests that Cuban health authorities need pay special attention to mortality by cancer [8].

Structurally the analysis is interesting too. In the whole period deaths by brain vascular illness represented the $12.1 \%$ annually from the whole mortality by the ten main death cause while death by flu and pneumonia only the $6.3 \%$ over the same base. These two death causes represent the $18.4 \%$ from all death causes and death by flu and pneumonia is the half from all death by brain vascular illness. However, the relevancy from health illness as death cause decreased at $0.2 \%$ annually while death by cancer increased at $0.3 \%$ annually, as shows the following graph. 


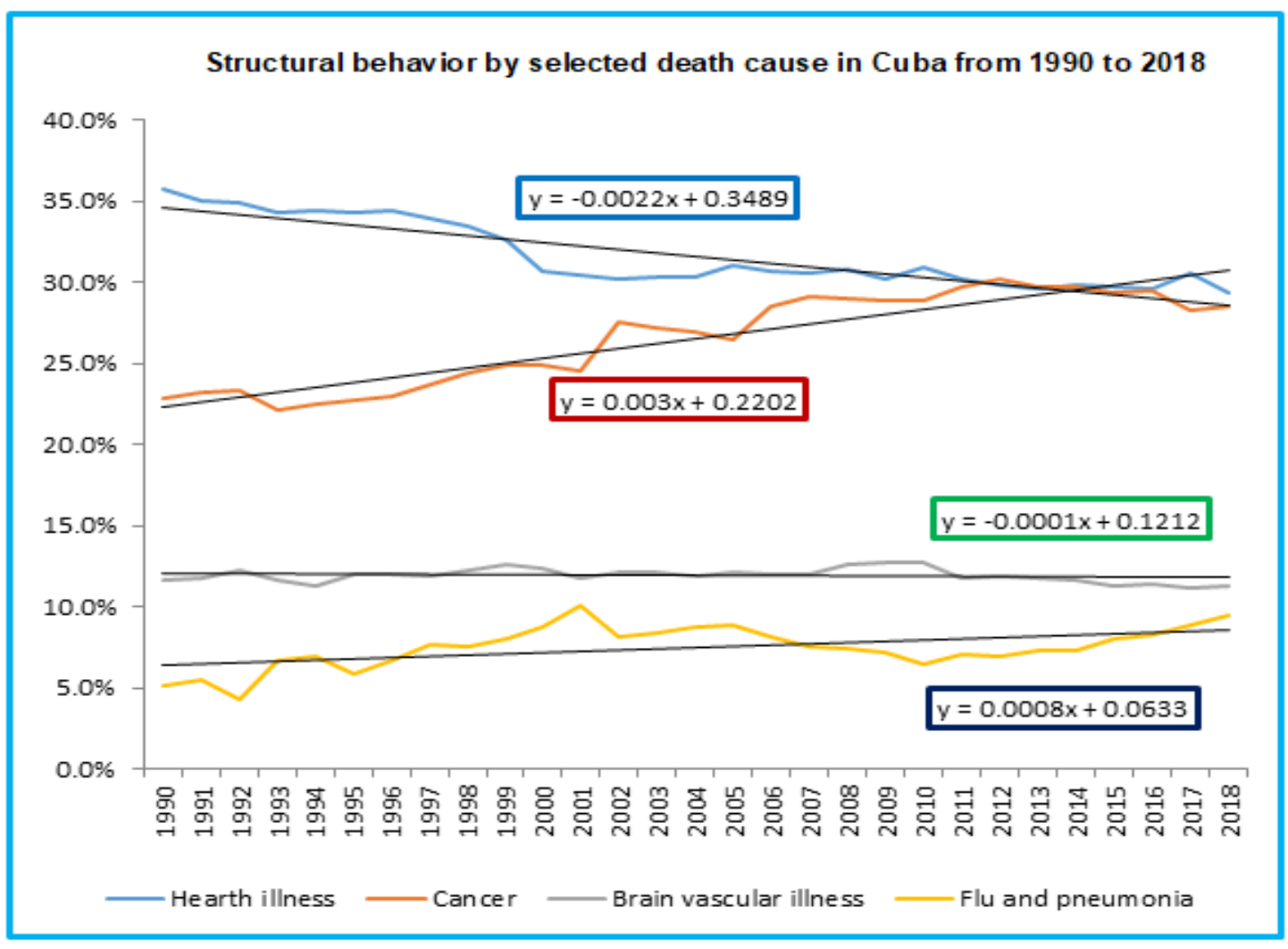

Graph made using information from the Cuban Statistic Yearbook

The middle incidence rate is close to 91 deaths annually by death cause. From the 10 main death causes in Cuba, Hearth illness, Cancer, Brain vascular illness and Flu and pneumonia are the most significant in the researched period. All these four death causes show a higher incidence rate than the middle from the ten, being the mortality by cancer the most relevant.

Structurally, mortality by brain vascular illness and flu and pneumonia are always around the $12.1 \%$ and $6.3 \%$ respectively. However, while mortality by hearth illness is decreasing, mortality by cancer always increases. The analysis from the whole behavior suggests that structurally there is an exclusivity relation between mortality by cancer and by hearth illness, although both death causes be growing. This conclusion suggest that the most important death cause in Cuba in the period researched is cancer [9].

Considering the life years' potentially lose the analysis is more precise. Agree to the Cuban Health Statistic Yearbook, patients affected with hearth illness show a higher overlife than patients affected with cancer. Cancer is a more aggressive morbidity and mortality cause than the hearth illness. Life expectancy living with cancer is less than living with a hearth illness. Then, cancer as morbidity and mortality cause need more effective consideration by the Cuban health authorities [10].

\section{Conclusions}

From the ten main death causes in Cuba from 1990 to 2018, Hearth illness, Cancer, Brain vascular illness and Flu and pneumonia are the more significant because all them are growing during all time researched. From these four death causes, Brain vascular illness and Flu and pneumonia save a structural behavior around the $12.1 \%$ and $6.3 \%$ respectively. However, Hearth illness is structurally decreasing and cancer is structurally growing.

\section{References:}

1. CM, Muños JA, Sáenz de Miera-Juárez B, et al. (2013) Consumo de tabaco, mortalidad y política fiscal en México. Salud Pública Méx. 55(Suppl 2):S276-S281

2. Rodríguez Cabrera AL, Gálvez González AM, Álvarez Vázquez L. (2018) Aspectos económicos del envejecimiento demográfico y su importancia para la toma de decisiones en el sector salud. El caso Cuba.

3. Arredondo A, Recaman AL, Pinzon C, Azar A. (2018) Financial consequences from smoking-related diseases in middle-income countries: Evidence and lessons from Mexico. Int J Health Plann Mgmt.33:e454-e463.

4. Rojas Ochoa, F. (2017) Conciliar prioridades entre Salud y Economía. Revista Cubana de Salud Pública. v. 43, n. 3, pp. 461-462. Disponible en: 〈>. ISSN 1561-3127

5. Toledo Curbelo GJ. (2008) Fundamentos de Salud Pública. Segunda edición. La Habana: Ciencias Médicas.

6. Sánchez González E., Fernández Hernández F. (2016) La pérdida de productividad laboral atribuible al tabaquismo. Revista Cubana de Salud y Trabajo.17(2):57-60

7. ONEI. Anuario Estadístico de Cuba.

8. Fernández Hernández F, Sánchez González E. (2020) The Smoking Economic Burden in the National Institute on Oncology and Radiology from Cuba. Journal of Physical medical \& Rehabitation studies \& Report. 2(2):1-3.

9. Pinto Márcia Teixeira, Pichon-Riviere Andres, Bardach Ariel. (2015 ) Estimación de la carga de enfermedad atribuible al tabaquismo en Brasil: mortalidad, morbilidad y costos. Cad. Saúde Pública 31(6): 1283-1297.

10. Ministerio de Salud Pública. Anuario Estadístico de Salud. 